\title{
REDESAIN TATA RUANG DAN KENYAMANAN PUSTAKAWAN DAN PEMUSTAKA DI PERPUSTAKAAN UNIVERSITAS AIRLANGGA
}

\author{
Ani Sistarina, Sukma Kartikasari
}

\begin{abstract}
ABSTRAK
Penelitian ini bertujuan untuk mengetahui apakah upaya redesain yang telah dilakukan oleh manajemen Perpustakaan Universitas Airlangga sudah sesuai dengan keinginan pemustaka dan pustakawan dan untuk mengukur apakah perubahan tersebut sudah memberikan efek kenyamanan dan kepuasan bagi pemustaka dan pustakawan. Penelitian ini melibatkan dua sampel responden yaitu pemustaka dan pustakawan di Perpustakaan Universitas Airlangga, dengan jumlah responden pemustaka sebanyak 100 orang, sedangkan jumlah responden pustakawan Perpustakaan Universitas Airlangga berjumlah 40 orang. Metode yang digunakan dalam penelitian ini adalah metode kuantitatif dengan tipe deskriptif. Teknik pengambilan data dengan cara menyebarkan kuesioner kepada responden pemustaka di Kampus B, sedangkan untuk pustakawan meliputi Kampus A, B, dan C. Data yang terkumpul kemudian dihitung, selanjutnya disusun dan disajikan dalam bentuk tabel. Penyusunan ini dilakukan dengan cara mengelompokkan data ke dalam indikator-indikator dari variabel yang telah ditentukan. Hasil penelitian ini menunjukkan bahwa Pemustaka dan Pustakawan Perpustakaan Universitas Airlangga merasa nyaman berada di perpustakaan karena desain perpustakaan yang meliputi tata ruang, tata warna, pencahayaan, sirkulasi udara, tata suara dan kenyamanan mampu memenuhi kebutuhan pemustaka dan pustakawan perpustakaan. Untuk masalah kebisingan, dibutuhkan peredam suara di masing-masing ruangan untuk meredam kebisingan agar semakin menambah kenyamanan bagi pemustaka dan pustakawan perpustakaan. Perubahan warna dinding secara berkala juga diperlukan untuk memberikan kesan fresh dan segar sehingga tidak monoton.
\end{abstract}

Kata kunci: Redesain, Tata Ruang, Kenyamanan Perpustakaan

\section{PENDAHULUAN}

Perpustakaan adalah sebuah komponen penting dalam sebuah lembaga, terlebih bagi Perguruan Tinggi. Penyelenggaraan Perpustakaan di perguruan tinggi juga telah diatur oleh undang-undang. Dalam Undang-undang Nomor 20 Tahun 2003 tentang Sistem Pendidikan Nasional pada pasal 55 menyebutkan bahwa salah satu syarat untuk menyelenggarakan Perguruan Tinggi harus memiliki Perpustakaan. Sedangkan Perpustakaan Perguruan Tinggi (PPT) merupakan Unit Pelaksana Teknis (UPT) yang bersama-sama dengan unit lain melaksanakan Tri Dharma Perguruan Tinggi dengan cara menghimpun, memilih, mengolah, merawat serta melayani sumber informasi kepada lembaga induk khususnya dan masyarakat akademis pada umumnya.
Jelas sudah bahwa keberadaan perpustakaan menjadi sesuatu yang penting dalam penyelenggaraan pendidikan di perguruan tinggi.

Perpustakaan memiliki beberapa fungsi pokok bagi pemustaka dalam pemanfaatannya. Seperti yang dikemukakan oleh Sulistyo-Basuki (1991: 27) bahwa perpustakaan memiliki beberapa fungsi yang meliputi:

1. Sebagai sarana simpan karya manusia

Perpustakaan memiliki fungsi sebagai tempat penyimpan karya manusia, khususnya karya cetak seperti buku, majalah dan sejenisnya dan juga karya rekaman seperti kaset, piringan hitam dan sejenisnya.

2. Fungsi informasi

Bagi masyarakat yang memerlukan informasi dapat berhubungan dan menanyakan ke perpustakaan.

\footnotetext{
* Pustakawan Perpustakaan Universitas Airlangga

E-mail: anisistarina@staf.unair.ac.id
} 


\section{Fungsi rekreasi}

Masyarakat dapat menikmati rekreasi kultural dengan cara membaca, dan bacaan ini disediakan oleh perpustakaan.

4. Fungsi pendidikan

Perpustakaan merupakan sarana pendidikan nonformal dan informal, artinya perpustakaan merupakan tempat belajar di luar bangku sekolah maupun juga tempat belajar dalam lingkungan pendidikan sekolah

5. Fungsi kultural

Perpustakaan memiliki fungsi sebagai tempat mendidik dan mengembangkan apresiasi budaya masyarakat.

Sebagai bentuk pemenuhan akan fungsi rekreatif, selain mengadakan sumber bacaan yang bersifat hiburan maka perpustakaan juga perlu memperhatikan tata ruang dan penataan ruang perpustakaan yang membuat pemustaka betah dan merasa nyaman. Banyak cara yang dilakukan pihak perpustakaan untuk menciptakan suasana perpustakaan yang nyaman baik bagi pemustaka maupun pustakawan selaku pengelola informasi nya. Salah satu cara yang bisa dilakukan oleh perpustakaan adalah melakukan redesain perpustakaan. Redesain dilakukan sebagai upaya untuk memberikan suasana baru pagi pemustaka dan pustakawan yang memberikan berimbas kepada rasa nyaman mereka.

Hal yang sama juga dilakukan oleh Perpustakaan Universitas Airlangga yang melakukan redesain perpustakaan dengan tujuan menjadikan tempat yang memberikan rasa nyaman sehingga baik permustaka maupun pustakawannya merasa betah memanfaatkan fasilitas perpustakaan. Redesain yang dilakukan Perpustakaan Unair adalah dengan melakukan perbaikan, perancangan ulang dan menambah unsur-unsur baru yang diharapkan mampu membawa perubahan menuju ke arah yang lebih baik tentunya.

Semua usaha yang dilakukan oleh Perpustakaan Universitas Airlangga ini bertujuan untuk memberikan yang terbaik bagi pemustaka dan juga pustakawan yang menjadi penyokong utama majunya sebuah perpustakaan. Akan tetapi apakah redesain perpustakaan tersebut benarbenar dapat dirasakan manfaatnya

Berdasarkan pemaparan diatas, Peneliti merasa tertarik untuk melakukan kajian penelitian tentang pengaruh redesain yang dilakukan oleh Perpustakaan Universitas Airlangga terhadap pemustaka, apakah mampu memberikan dampak yang positif dan bagi pustakawan apakah perubahan tersebut membawa kenyamanan yang berdampak kepada peningkatan produktivitas kerja.

\section{TINJAUAN PUSTAKA}

\section{Redesain}

Kata redesain merupakan kata yang diadopsi dari bahasa Inggris, yang terdiri dari 2 unsur kata yaitu re- dan desain. Penggunaan "re-" mengacu pada pengulangan atau melakukan kembali. Berdasarkan Kamus Besar Bahasa Indonesia (2008: 348) kata desain dan interior memiliki arti motif atau corak ruang dalam gedung.

Dari pengertian tersebut dapat disimpulkan bahwa, redesain adalah suatu kegiatan merancang ulang kembali suatu objek (benda, bangunan, atau suatu sistem) sehingga dapat memiliki pola susunan, kerangka bentuk ruangan, motif bangunan, pola bangunan, dan corak bangunan yang berbeda dari desain sebelumnya, atau untuk menghasilkan manfaat yang lebih baik dari desain sebelumnya. Ditambah lagi kegiatan redesain ini dilakukan dengan beberapa cara seperti mengubah, mengurangi, ataupun menambahkan unsur tertentu pada objek yang di redesain.

\section{Tata Ruang}

Suptandar dalam bukunya "Manusia dan Ruang dalam Proyeksi Desain Interior" (1993: 11) menuliskan bahwa desain interior perpustakaan adalah cara dalam menata tata ruang bagian dalam dari suatu gedung perpustakaan, yang berfungsi sebagai wadah segala kegiatan dan aktivitas di perpustakaan dengan menciptakan suasana dan citra ruang yang nyaman dan aman dengan memperhatikan kebutuhan individu-individu di dalamnya tanpa mengabaikan faktor estetika. Pendapat beberapa ahli seperti Ching (1996: 46) mendefinisikan desain interior sebagai kegiatan merencanakan, menata, dan merancang ruang interior dalam bangunan yang berfungsi untuk memenuhi kebutuhan dasar akan sarana untuk bernaung dan berlindung, menentukan sekaligus mengatur aktivitas, memelihara aspirasi dan mengekspresikan ide, tindakan serta penampilan, perasaan, dan kepribadian. Adapun tujuannya adalah untuk memperbaiki fungsi, memperkaya nilai estetika dan meningkatkan aspek psikologis dari ruang interior.

Adapun pengertian desain interior menurut Sachari (1986: 23) yaitu merupakan keterampilan pengetahuan dan pengalaman manusia yang mencerminkan keterikatannya 
dengan apresiasi dan adaptasi terhadap lingkungannya dalam memenuhi kebutuhan-kebutuhan material dan spiritual yang secara khusus terkait dengan konfigurasi, komposisi, arti nilai, dan tujuan dari fenomena buatan manusia.

Dalam penataan interior ruangan ada beberapa unsur yang perlu diperhatikan. Darmono (2001: 205) menyatakan bahwa unsur kelengkapan-kelengkapan khusus dalam penataan ruangan yang perlu diperhatikan adalah tingkat intensitas penerangan, pengaturan udara dan ventilasi, warna-warna yang diinginkan, tata letak serta pengaturan akustik ruangan agar kedap suara dan tidak menimbulkan pantulan gelombang suara yang menyebabkan ruangan menjadi bergema. Menurut Cohen (1994: 547) terdapat beberapa faktor yang memengaruhi desain interior suatu gedung yaitu ruang, warna, pencahayaan, sirkulasi udara dan tata suara. Berikut ini adalah uraiannya:

Menurut Lasa (2005: 157) pada dasarnya kebutuhan ruang perpustakaan dialokasikan untuk koleksi, pemakai, staf, dan keperluan lain. Untuk itu perlu dipertimbangkan sistem pinjam yang akan dianut oleh suatu perpustakaan, dengan sistem pinjam terbuka (open access) atau sistem pinjam tertutup (closed access). Lebih lanjut dijelaskan Lasa (2005: 157) apabila perpustakaan tersebut menganut sistem tertutup, maka alokasinya adalah $45 \%$ untuk koleksi, 25\% untuk pengguna, 20\% untuk staf, dan $10 \%$ untuk keperluan lain. Apabila perpustakaan tersebut menganut sistem terbuka, maka alokasinya diatur dengan pembagian $70 \%$ untuk koleksi dan pengguna, $20 \%$ untuk staf, dan yang $10 \%$ untuk keperluan lain.

Menurut Ching (1996: 71) kebutuhan luas ruang dibedakan dalam tiga jenis yaitu: kebutuhan luas ruang terhadap banyaknya orang yang dilayani, perlengkapan yang dibutuhkan, dan aktivitas yang dilakukan. Sedangkan menurut Poole (1981: 60) kebutuhan akan menganalisa jumlah pemakai dan jumlah peralatan perlu dilakukan dalam merancang suatu ruang perpustakaan. Ruang perpustakaan yang baik hendaknya memenuhi kriteria sebagai berikut: kefleksibelan atau keluwesan, dapat menanggung beban lantai, mudah untuk diperluas, kesederhanaan dalam desain, melihat kebutuhan ruangan di masa yang akan datang, menjelaskan pilihan-pilihan macam desain interior ruang dalam perpustakaan.

\section{Tata Warna}

Menurut Pamudji (2003: 159) pemilihan warna dapat memengaruhi kondisi seorang pemustaka, dimana warna pada dinding, lantai, atap dan perabot dapat menciptakan suasana hati dan kenyamanan seseorang.

Berdasarkan penjelasan Lasa (2005: 164) warna akan memengaruhi orang yang bekerja dan membaca di perpustakaan. Warna juga akan memperbesar konsentrasi dan memengaruhi jiwa seseorang. Tiap warna secara psikologis memiliki pengaruh yang berbeda-beda terhadap perilaku dan sikap manusia. Hal ini senada dengan yang dikemukakan oleh Sutton (dalam Adianto, 2011: 17) bahwa warna dapat memberikan suasana tertentu pada suatu ruangan, karena setiap macam warna memiliki karakter sendiri-sendiri, selain itu setiap warna juga memiliki efek psikologis, berikut adalah penjelasan dari beberapa macam warna:

a) Merah, merupakan warna yang paling memacu detak jantung, warna yang mengarahkan dalam spectrum, mengekspresikan kesenangan, kecepatan, tenaga, kegembiraan, bahaya, serta emosi. Merah membuat orang merasa lebih hangat

b) Kuning, secara psikologis merupakan warna yang paling gembira dalam spectrum, diasosisikan dalam kehangatan, optimisme dan kesukaan. Kuning biasanya langsung muncul di depan mata, membuatnya paling mudah dikenali daripada warna lain. Kuning menstimulasi kejernihan pikiran, kuning menambah kekuatan pada warna lain, membuat warna hangat semakin cemerlang dan warna dingin menjadi lebih hidup. Penggunaan warna kuning terang yang terlampau banyak membuat tidak nyaman, kuning yang lebih pucat lebih bersahabat.

c) Oranye, merupakan warna yang menstimulasi, secara bersahabat memberi semangat, gembira, dan berpetualang. Oranye terang sangat mudah dilihat, membuatnya cocok untuk sinyal bahaya atau penarik perhatian, bahkan bila digunakan pada area kecil karena oranye bersifat main-main hingga membuatnya menjadi warna favorit anak-anak.

d) Hijau, hijau pucat secara psikologis paling mengistirahatkan dan menenangkan dalam spectrum. Sebagai warna yang paling mudah dalam mata, hijau dapat meningkatkan penglihatan.

e) Biru, umumnya biru diasosiasikan dengan hal-hal baik, dan warna yang damai. Biru dapat membuat sebuah ruang terlihat lebih luas.

f) Ungu, memancarkan kelas, kekuatan emosi, sensualitas, dan kemewahan. Orang cenderung untuk malas bekerja dalam ruangan ungu karena ungu mendorong orang untuk melamun. 
g) Merah muda, adalah warna yang paling pasif. Merah muda menenangkan dan melembutkan.

h) Coklat adalah warna yang hangat, menyamankan, diasosiasikan dengan bumi, pohon, hati, dan rumah.

i) Abu-abu, memberi kesan formal, terhormat, kekuasaan, konservatif.

j) Putih, menyimbolkan kemurnian, tak bersalah, kebaikan, dan kebenaran. Warna putih sering digunakan untuk menunjukkan kesederhanaan, kesterilan, dan keamanan.

k) Hitam, merupakan warna yang paling mendiktator, mengintimidasi, bisa membuat kesan agresif bila digunakan di banyak tempat. Hitam memberi perasaan berat dan dalam. Teks sulit dibaca pada latar belakang hitam.

\section{Pencahayaan}

Menurut Pamudji (2006: 5) kegiatan di dalam ruang termasuk kegiatan bekerja, membutuhkan sistem pencahayaan yang efektif. Sumber penerangan dapat berasal dari cahaya buatan dan cahaya alami. Pencahayaan merupakan faktor yang paling penting dalam desain interior karena menurut Sehgal (2012: 3) cahaya merupakan energi yang terpancar dan membantu manusia untuk melihat ruang interior. Dengan adanya cahaya yang membantu manusia untuk melihat, maka manusia akan merasa nyaman secara visual dan dapat melakukan aktivitasnya sehari-hari.

Masih menurut Sehgal (2012: 4) terdapat dua jenis pencahayaan yang digunakan dalam kantor yaitu pencahayaan alami atau natural light yang berasal dari matahari dan pencahayaan buatan yang terdapat di dalam ruangan yaitu lampu. Cahaya alami atau natural light berasal dari cahaya matahari yang masuk melalui jendela, pintu kaca, ventilasi, dan lain sebagainya. Sedangkan pencahayaan buatan biasanya dipasang di langit-langit kantor dan digunakan untuk memberi cahaya ke seluruh ruangan agar dapat digunakan untuk menerangi area kerja pustakawan.

\section{Sirkulasi Udara (Ventilasi)}

Sulistyo-Basuki (1991: 130) menyatakan bahwa perpustakaan yang terang dan sejuk berkat ventilasi yang baik akan lebih besar peluangnya untuk menarik perhatian pengunjung serta menyenangkan staf perpustakaan.

Menurut Kroemer dan Grandjean (1997: 359) tingkat kelembapan optimum di dalam ruang kantor adalah sekitar 50 persen dan tingkat kelembapan 40 sampai
60 persen akan menghasilkan kenyamanan pegawai. Selain itu, adanya ventilasi juga dapat memengaruhi temperatur udara di dalam ruangan. Ventilasi berguna untuk kelancaran pergantian sirkulasi udara di dalam ruangan sehingga udara menjadi stabil dan terhindar dari gangguan pernafasan atau gangguan fisik lainnya.

Purwati (dalam Adianto, 2011: 23) menyatakan bahwa, terdapat 2 macam sistem ventilasi atau sirkulasi udara yang digunakan perpustakaan yaitu:

a) Ventilasi pasif adalah ventilasi yang didapat dari alam. Caranya membuat lubang angina tau jendela pada sisi dinding yang berhadapan serta sejajar dengan arah angin lokal. Luas lubang angin atau jendela diusahakan sebanding persyaratan dan fasilitas ruang (10\% dari ruang bersangkutan). Bila menggunakan ventilasi pasif seperti ini sebaiknya rak tidak ditempatkan dekat jendela demi keamanan koleksi dan terhindar dari matahari langsung.

b) Ventilasi aktif adalah ventilasi yang menggunakan sistem penghawaan buatan menggunakan AC (Air Conditioning). Dengan temperatur dan kelembapan ruang perpustakaan yang stabil maka dapat menjaga keawetan koleksi dan peralatan tertentu seperti koleksi langka, pandang dengar dan komputer.

\section{Tata Suara (Akustik)}

Menurut Sehgal (2012: 3) polusi suara atau disebut juga dengan kebisingan merupakan suara yang tidak dikehendaki dan mengganggu manusia ketika melakukan aktifitasnya. Kroemer dan Grandjean (1997: 326) membagi jenis kebisingan yang terdapat di lingkungan kantor menjadi 2, yaitu kebisingan eksternal dan kebisingan internal. Kebisingan eksternal atau yang berasal dari luar seperti lalu lintas (traffic), industry, dan neighbours. Sedangkan kebisingan yang berasal dari internal kantor seperti telepon, keyboard komputer, printer, kipas angin, dan orang yang berbincang-bincang.

Efek dari kebisingan yang terjadi secara terus menerus menurut Kroemer dan Grandjean (1997: 332) adalah kesulitan konsentrasi, mengganggu jalannya pikiran dan berkreatifitas dalam bekerja sehingga menimbulkan pengaruh pada performansi kerja. Masih menurut Kroemer dan Grandjean (1997: 335) tingkat toleransi kebisingan di dalam ruang perpustakaan adalah 70 desibel hingga 75 desibel. Suara-suara seperti lalu lintas biasanya hanya mencapai 50 desibel sampai 75 desibel, sedangkan suara alat-alat yang terdapat di perpustakaan seperti kipas angin, keyboard komputer, 
printer, mesin fotokopi, dan lain sebagainya biasanya hanya mencapai 40 sampai 75 desibel.

\section{Kenyamanan}

Menurut Kamus Besar Bahasa Indonesia (1994: 695) kenyamanan berarti keadaan nyaman, kesegaran, kesejukan. Lasa (2005: 130) berpendapat bahwa dalam pelaksanaan kegiatan perpustakaan diperlukan kenyamanan, keselamatan, dan keamanan kerja. Pustakawan sebagai tenaga kerja yang berperan sebagai pendukung utama kegiatan perpustakaan, dalam pelaksanaannya memerlukan keselamatan, kenyamanan, dan keamanan kerja. Sedangkan menurut Suryabrata (1991: 95) seseorang pengguna perpustakaan dapat dikatakan nyaman berada di ruangan, jika dilihat dari seberapa betah dan bisa berkonsentrasi ketika belajar atau melakukan aktivitas lainnya di dalam ruangan. Oleh karena itu, pengaturan tata ruang dalam sebuah perpustakaan sangat berpengaruh bagi kenyamanan pemustaka.

Lasa dalam bukunya "Manajemen Perpustakaan" (2005: 157) mengatakan bahwa dalam perencanaan ruangan perlu dipertimbangkan bahwa keserasian dalam penataan ruang akan memengaruhi produktivitas, efisiensi, efektivitas, dan kenyamanan pemakai. Lebih lanjut Lasa (2005: 161) menyatakan bahwa produktivitas manusia yang bekerja di ruangan dipengaruhi oleh faktor pribadi (internal) dan faktor di luar dirinya (eksternal). Perasaan, emosi, motivasi, kesehatan, dan keyakinan seseorang memengaruhi produktivitas mereka. Demikian pula lingkungan kerja sebagai faktor eksternal akan memengaruhi hasil kerja seseorang, hasil kerja seseorang akan baik apabila ditunjang dengan kondisi lingkungan yang baik.

Sulistyo-Basuki (1991: 303) dalam bukunya mengatakan bahwa Perancangan gedung yang baik akan menghasilkan tempat kerja yang efisien, nyaman, dan menyenangkan bagi staf perpustakaan maupun pengunjung. Senada dengan hal tersebut, Lasa (2005: 149) juga menyatakan bahwa ruang perpustakaan akan nyaman bagi pemakai dan petugas apabila ditata dengan memperhatikan fungsi, keindahan, dan keharmonisan ruang. Dengan penataan yang baik akan memberikan kepuasan fisik dan psikis bagi penghuninya.

\section{Pustakawan}

Pustakawan menurut Sulistyo-Basuki adalah tenaga profesional yang dalam kehidupan sehari- hari berkecimpung dengan dunia buku (1991: 159). Sedangkan menurut Wiji Suwarno (2009:62) pustakawan atau librarian adalah seorang tenaga kerja di bidang perpustakaan yang telah memiliki pendidikan ilmu perpustakaan, baik melalui pelatihan, kursus, seminar, ataupun dengan kegiatan sekolah formal.

Menurut Undang-Undang Nomor 43 Tahun 2007 tentang perpustakaan dijelaskan bahwa pustakawan adalah seseorang yang memiliki kompetensi yang diperoleh melalui pendidikan dan/atau pelatihan kepustakawanan serta mempunyai tugas dan tanggung jawab untuk melaksanakan pengelolaan dan pelayanan perpustakaan.

Berdasarkan Standar Nasional Perpustakaan (SNP) Tahun 2011 mengenai standar nasional perpustakaan perguruan tinggi, dijelaskan bahwa pustakawan perguruan tinggi ialah pustakawan yang berpendidikan serendahrendahnya sarjana di bidang ilmu perpustakaan dan informasi, dan diberi tugas, tanggung jawab, wewenang, dan hak secara penuh oleh pejabat yang berwenang untuk melakukan kegiatan kepustakawanan di perpustakaan.

\section{Pemustaka}

Dalam buku "Layanan Cinta: Perwujudan Layanan Prima ++ Perpustakaan" disebutkan bahwa menurut Undang-Undang tentang Perpustakaan Tahun 2007 pemustaka adalah pengguna perpustakaan, yaitu perseorangan, kelompok orang, masyarakat, atau lembaga yang memanfaatkan fasilitas layanan perpustakaan (2012: 35). Pemustaka biasa juga disebut dengan pengguna atau user. Menurut Wiji Suwarno (2009: 80) terdapat beberapa macam jenis pemustaka atau user di perpustakaan Perguruan Tinggi yaitu, mahasiswa, dosen, karyawan, maupun masyarakat civitas academic tergantung dari kebijakan perpustakaan Perguruan Tinggi tersebut. Sedangkan menurut Reitz (2004: 527) user is any person who the resources and services of library. Maksudnya adalah pemustaka ialah setiap orang yang menggunakan fasilitas dan layanan yang ada di perpustakaan.

\section{METODE PENELITIAN}

Metode yang digunakan dalam penelitian ini adalah metode kuantitatif dengan tipe deskriptif. Metodologi kuantitatif deskriptif menurut Taylor (Pendit, 2003: 194) merupakan sebuah penelitian yang bertujuan menyajikan gambaran (deskripsi) tentang sebuah fenomena secara valid dan objektif, sesuai dengan prinsip-prinsip objektivisme - positivisme yang sudah dikembangkan 
berabad-abad oleh ilmu pasti alam. Sedangkan penelitian deskriptif dimaksudkan untuk eksplorasi dan klarifikasi mengenai suatu fenomena atau kenyataan sosial (Faisal, 2007: 20). Populasi dalam penelitian ini adalah pustakawan dan pemustaka perpustakaan Universitas Airlangga.

Untuk pengambilan jumlah sampel pemustaka dalam penelitian ini akan digunakan rumus sampling Yamane, dimana ukuran sampel dihitung berdasarkan pada pendugaan proporsi populasi. Menurut Yamane (dalam Rakhmat, 1998: 82) rumusnya adalah sebagai berikut:

$$
\mathrm{n}=\frac{\mathrm{N}}{\mathrm{Nd}^{2}+1}
$$

Keterangan :

$\mathrm{n}=$ Jumlah sampel

$\mathrm{N}=$ Jumlah populasi

$\mathrm{d}^{2}=$ Presisi yang ditetapkan sebesar $10 \%$

Maka, jumlah sampel minimum yang diperoleh adalah:

$$
\begin{aligned}
\mathrm{n} & =\frac{1500}{(1500)(0,1)^{2}+1} \\
& =93,75
\end{aligned}
$$

Besarnya jumlah populasi yang diambil diatas adalah berdasarkan jumlah rata-rata pengunjung per harinya pada bulan Maret 2017 di Perpustakaan Universitas Airlangga yaitu 1.500 pengunjung. Dari perhitungan rumus diatas diperoleh hasil 93,75. Namun, untuk meningkatkan akurasi data, maka jumlah sampel pemustaka digenapkan menjadi 100 orang responden.

Sedangkan untuk pustakawan, sampel yang diambil adalah pustakawan yang kooperatif dalam mendukung penelitian ini. Dari pustakawan yang kooperatif tersebut maka diambil 40 orang sebagai sampel penelitian.

\section{PEMBAHASAN}

\section{Tata Ruang}

Menurut pemustaka perpustakaan dan pustakawan Universitas Airlangga pada bagian tata ruang yang terdiri dari beberapa pertanyaan yang meliputi penataan tata ruang, kelengkapan perabot, pemisahan ruangan, jarak perabot di dalam setiap ruangan, luas ruangan, desain rak buku, hiasan ruangan, penempatan perabot, dari semua pertanyaan memiliki nilai tertinggi pada bagian setuju, dan ada beberapa responden yang juga memilih sangat setuju. Hal ini bisa diartikan bahwa pengaruh redesain tata ruang memberikan kenyamanan bagi pustakawan dan pemustaka. Meskipun hasilnya memuaskan Perpustakaan Universitas Airlangga tidak lantas berpuas diri dengan hasil tersebut, karena ada beberapa responden masih belum merasakan kenyamanan terhadap penataan tata ruang yang ada di Perpustakaan Universitas Airlangga.

\section{Tata Warna}

Pada bagian tata warna yang terdiri dari beberapa pertanyaan yang meliputi warna cat dinding di setiap ruangan, warna lantai atau karpet, warna perabot, perpaduan warna cat dinding dan lantai atau karpet sudah sesuai, pengaruh warna terhadap konsentrasi, pengaturan warna membuat perpustakaan menjadi lebih bersih menarik dan indah, perlunya perpustakaan memiliki warna yang khas, perlunya perubahan cat dinding secara berkala. Dari semua pertanyaan yang telah diajukan memiliki nilai tertinggi pada bagian setuju, dan ada beberapa yang memilih sangat setuju. Hal tersebut dapat diartikan bahwa tata warna memiliki pengaruh yang sangat besar terhadap kenyamanan dan kepuasan pemustaka dan pustakawan Perpustakaan Universitas Airlangga. Meskipun begitu masih ada beberapa yang kurang setuju bahkan ada yang sangat tidak setuju, ini berarti diperlukan ada perbaikan agar tata warna yang ada di perpustakaan menjadi lebih baik lagi sehingga menimbulkan kepuasan dan kenyamanan bagi seluruh pemustaka dan pustakawan perpustakaan.

\section{Pencahayaan}

Pada bagian pencahayaan ada beberapa pertanyaan yang diajukan, pertanyaan tersebut meliputi apakah penerangan sudah merata dan terang, kuat lemahnya cahaya di setiap ruang sudah sesuai, cahaya matahari bisa masuk ke setiap ruangan di perpustakaan, pancaran sinar lampu dan matahari sudah sama baiknya menyinari ruangan di perpustakaan, pencahayaan sudah baik untuk mendukung semua aktivitas dan yang terakhir apakah cahaya lampu tidak menyilaukan mata. Dari semua jawaban atas pertanyaan diatas jawaban tertinggi adalah pada kolom setuju dan ada pula yang sangat setuju, hal ini berarti bahwa pencahayaan yang ada di setiap ruangan yang ada di perpustakaan sudah cukup bagus dan mempermudah semua aktivitas pemustaka. Hasil diatas bukan lantas membuat puas, akan tetapi masih perlu juga di perhatikan bahwa beberapa responden masih ada yang memilih tidak setuju dan sangat tidak setuju, atas dasar 
ini dapat dijadikan acuan oleh pihak manajemen untuk melakukan perubahan dan perbaikan agar pencahayaan yang ada di perpustakaan lebih baik lagi.

\section{Sirkulasi Udara}

Pada bagian ini pertanyaan yang diajukan adalah seputar sirkulasi udara yang ada di setiap ruangan di perpustakaan. Dari beberapa pertanyaan tersebut mayoritas responden memilih setuju dan ada juga yang memilih sangat setuju. Ada sedikit perbedaan jawaban mayoritas antara responden pemustaka dan pustakawan, yaitu pada pertanyaan tentang pengharum ruangan yang ada di setiap ruangan di perpustakaan. Mayoritas pemustaka menjawab setuju sedangkan mayoritas dari responden yang berasal dari pustakawan menjawab tidak setuju. Dari hasil mayoritas yang menjawab setuju menunjukkan bahwa sirkulasi udara yang ada di perpustakaan sudah lebih baik, akan tetapi harus lebih diperhatikan untuk melakukan perbaikan mengingat masih ada beberapa responden yang memilih tidak setuju bahkan sangat tidak setuju.

\section{Tata Suara}

Tata suara merupakan bagian yang tak kalah penting bagi kenyamanan pemustaka yang berkunjung ke perpustakaan. Dari beberapa pertanyaan yang diajukan masalah kebisingan yang terjadi di perpustakaan mayoritas responden menyatakan setuju, ini berarti bahwa kebisingan yang terjadi di dalam perpustakaan mengganggu kenyamanan pemustaka dan pustakawan di perpustakaan. Pemustaka dan pustakawan menginginkan adanya pemutaran musik yang lembut di perpustakaan. Nilai tertinggi pada kolom setuju dapat diartikan bahwa tata suara yang ada di perpustakaan sudah mampu mendukung kenyamanan pemustaka dan pustakawan di perpustakaan. Hal ini bukan lantas membuat perpustakaan berbangga diri tetapi perbaikan perlu terus dilakukan mengingat masih ada responden yang memilih tidak setuju dan bahkan sangat tidak setuju.

\section{Kenyamanan}

Beberapa pertanyaan pada bagian kenyamanan yang meliputi apakah responden betah berlama-lama berada di perpustakaan karena fasilitas yang disediakan, perasaan aman responden ketika berada di perpustakaan dan didukung dengan tersedianya CCTV di setiap ruangan, kemudahan berkonsentrasi ketika berada di perpustakaan, fasilitas dan perabot yang ada di perpustakaan dapat berfungsi dengan baik, adanya sarana dan fasilitas pendukung di setiap ruangan yang ada di perpustakaan. Dari semua pertanyaan yang diajukan jawaban tertinggi pada bagian setuju dan beberapa pada bagian sangat setuju, hal ini dapat diartikan bahwa pemustaka sudah merasa nyaman berada dalam perpustakaan. Meskipun begitu harus dilakukan perbaikan mengingat masih ada responden yang memilih tidak setuju dan sangat tidak setuju.

\section{PENUTUP}

Hasil penelitian ini menunjukkan bahwa Pemustaka dan Pustakawan Perpustakaan Universitas Airlangga merasa nyaman berada di perpustakaan karena desain perpustakaan yang meliputi tata ruang, tata warna, pencahayaan, sirkulasi udara, tata suara dan kenyamanan mampu memenuhi kebutuhan pemustaka dan pustakawan perpustakaan. Untuk masalah kebisingan, dibutuhkan peredam suara di masing-masing ruangan untuk meredam kebisingan agar semakin menambah kenyamanan bagi pemustaka dan pustakawan perpustakaan. Perubahan warna dinding secara berkala juga diperlukan untuk memberikan kesan fresh dan segar sehingga tidak monoton.

Berdasarkan hasil dari penulisan tersebut beberapa saran yang dapat penulis berikan adalah sebagai berikut:

1. Perpustakaan Universitas Airlangga perlu menambahkan peredam suara di masing-masing ruangan untuk mengurangi kebisingan di perpustakaan.

2. Perpustakaan perlu menambahkan pengharum di setiap ruangan baik ruangan di bagian layanan maupun ruangan pustakawan atau administrasi.

3. Menambahkan alunan musik yang lembut yang diperdengarkan melalui pengeras suara yang ada di setiap ruangan yang ada di Perpustakaan Universitas Airlangga.

4. Perubahan warna cat dinding yang dilakukan secara berkala agar memberikan kesan segar atau fresh sehingga tidak monoton.

\section{DAFTAR PUSTAKA}

Achmad, dkk. 2012. Layanan Cinta: Perwujudan Layanan Prima ++ Perpustakaan. Jakarta: Sagung Seto. 
Adianto, Alfian. 2011. Skripsi. Pengaruh Desain Interior Perpustakaan terhadap Tingkat Frekuensi Mengunjungi Perpustakaan. Surabaya: Universitas Airlangga.

Bungin, M. Burhan. 2011. Metodologi Penelitian Kuantitatif : Komunikasi, Ekonomi, dan Kebijakan Publik serta Ilmu-ilmu Sosial Lainnya. Jakarta : Kencana.

Ching, Francis D.K. 1996. Ilustrasi Desain Interior. Jakarta: Airlangga.

Cohen, Elaine. 1994. Journal LIBRARY TRENDS. The Architectural and Interior Design: Planning process, Vol. 42, (3), Winter, pp. 547-563. USA: The Board of Trustees of The University of Illinois.

Darmono. 2001. Manajemen dan Tata Kerja Perpustakaan Sekolah. Jakarta: Grasindo.

Depdiknas RI. 2004. Perpustakaan Perguruan Tinggi: Buku Pedoman. Jakarta: Departemen Pendidikan Nasional RI.

Faisal, Sanapiah. 2007. Format-format Penelitian Sosial. Jakarta : Raja Grafindo Persada.

Kroemer K.H.E. and E. Grandjean. 1997. Fitting the Task to the Human Fifth Edition: A Textbook of Occupational Ergonomics. London: Taylor \& Francis Inc.

Lasa HS. 2005. Manajemen Perpustakaan. Yogyakarta: Gama Media.

Mutia, Fitri. 2012. Desain Ruang Perpustakaan. Surabaya: PT. Revka Petra Media.

Noor, Juliansyah. 2011. Metodologi Penelitian : Skripsi, Tesis, Disertasi, dan Karya Ilmiah. Jakarta : Kencana.

Pendit, Putu Laxman. 2003. Penelitian Ilmu Perpustakaan dan Informasi. Jakarta: JIP-FSUI.

Perpustakaan Nasional RI. 2011. Standar Nasional Perpustakaan (SNP). Diakses melalui http://www. perpusnas.go.id/assets/uploads/2016/10/standar_ nasional_perpustakaan-sekolah.pdf. pada tanggal 2 Maret 2017.

Poole, Frazer G. 1981. Dasar Perencanaan Gedung Perpustakaan Perguruan Tinggi di Indonesia. Bandung: Penerbit ITB.

Pusat Bahasa Departemen Pendidikan Nasional. 2008. Kamus Bahasa Indonesia, Ed. 4. Jakarta: Pusat Bahasa.

Rakhmat, Jalaluddin. 1998. Metode Penelitian Komunikasi. Bandung: Remaja Rosdakarya.

Reitz, Joan M. 2004. Dictionary for Library and Information Science. USA: Library Unlimited.
Sachari, Agus. 1986. Paradigm Design Indonesia. Jakarta: Rajawali Press.

Sehgal, Shruti. 2012. International Journal of Engineering Research and Applications (IJERA). Relationship between Work Environment and Productivity, Vol.2, Issue 4, July-August, pp. 1992-1995. Diakses melalui http:// www.ijera.com /papers /Vol2_issue4/ LY2419921995.pdf. pada tanggal 1 Maret 2017.

Soehartono, Irawan. 1999. Metode Penelitian Sosial. Bandung: Remaja Rosdakarya.

Sugiyono. 2010. Metode Penelitian Kuantitatif Kualitatif dan $R \& D$. Bandung: Alfabeta.

Sugiyono. 2009. Metode Penelitian Kuantitatif Kualitatif dan $R \& D$. Bandung: Alfabeta.

Sulistyo-Basuki. 1991. Pengantar Ilmu Perpustakaan. Jakarta: Gramedia Pustaka Utama.

Suptandar, Pramudji. 1993. Manusia dan Ruang dalam Proyeksi Desain Interior. Jakarta: UPT Penerbitan Universitas Tarumanegara.

Suptandar, Pramudji. 2003. Perancangan Tata Ruang dalam Desain Interior. Jakarta: PT. Djambatan.

Suptandar, Pramudji. 2006. Sistem Pencahayaan pada Desain Interior. Jakarta: Penerbit Universitas Trisakti.

Suryabrata, Sumadi. 1991. Psikologi Kepribadian. Jakarta: Rajawali.

Suwarno, Wiji. 2009. Psikologi Perpustakaan. Jakarta: Sagung Seto.

Tim Penyusun Kamus Pusat Pembinaan dan Pengembangan Bahasa. 1994. Kamus Besar Bahasa Indonesia, Ed. 2. Jakarta: Balai Pustaka.

Undang- undang Republik Indonesia. 2003. Undang-undang No. 20 Tahun 2003 Tentang Sistem Pendidikan Nasional. Diakses melalui http://sindikker. dikti.go.id/dok/UU/UU20-2003-Sisdiknas.pdf. pada tanggal 2 Maret 2017.

Undang-undang Republik Indonesia. 2007. Undangundang No.43 Tahun 2007 Tentang Perpustakaan. Jakarta: Perpustakaan Nasional Republik Indonesia. Diakses melalui http://kelembagaan.pnri.go.id/ Digital_Docs/pdf/aboutus/official_archives/public/ normal/PP\% 20Nomor\%2024\%20Tahun\%202014. pdf. pada tanggal 2 Maret 2017.

Zed, Mustika. 2004. Metodologi Penelitian Kepustakaan. Jakarta: Obor Indonesia. 